\title{
Hyponatremia and Voltage Gated Potassium Channel Antibody Associated Limbic Encephalitis Newey $C^{1 *}$ and Sarwal $A^{2}$
}

${ }^{1}$ Cleveland Clinic 9500 Euclid Avenue Cleveland, OH 44195-5245, USA

${ }^{2}$ Neurology and Critical Care, Wake Forest Baptist Medical center, Medical Center Boulevard Winston Salem, USA

\begin{abstract}
Limbic encephalitis may occur as an infectious, paraneoplastic, or autoimmune phenomenon. One such cause of limbic encephalitis is voltage gated potassium channel antibodies (VKGC). Hyponatremia with new cognitive decline may be one of the presenting symptoms. The exact mechanism of hyponatremia is unknown though findings consistent with syndrome of inappropriate antidiuretic hormone (SIADH) are observed. We retrospectively reviewed all cases admitted to an academic medical center with a diagnosis of limbic encephalitis (848 adults between 2004 to 2010) and found six cases of VGKC antibody associated limbic encephalitis. Three of the six cases had SIADH that completely or partially resolved with a combination of water restriction and immunotherapy. The reversibility of hyponatremia and limbic encephalitis with immunomodulation suggests an antibody-mediated cause. We further review available literature for association of hyponatremia and VGKC limbic encephalitis and propose mechanisms of for the hyponatremia in autoimmune encephalitis.
\end{abstract}

Keywords: VGKC; Hyponatremia; Limbic encephalitis

\section{Introduction}

Limbic encephalitis (LE) may occur as a paraneoplastic or autoimmune phenomenon and may be associated with syndrome of inappropriate anti-diuretic hormone secretion (SIADH). Ectopicantibody production can explain SIADH in paraneoplastic cases but the exact mechanism of hyponatremia in antibody-mediated LE, such as voltage gated potassium channel (VGKC), is unknown.

VGKC antibodies have been reported in association with several clinical syndromes involving the central and peripheral nervous systems [1,2]. However, only VGKC-LE has been found associated with hyponatremia with an incidence between $30-100 \%$ [3-5]. We present here a retrospective review of our cases of limbic encephalitis with a case series of VGKC-LE and its association of SIADH and review of literature discussing the possible mechanism.

\section{Methods}

We retrospectively reviewed medical charts of 848 adults from 2004-2010 who were clinically diagnosed with LE. Charts were reviewed for paraneoplastic panel, SIADH workup, basic metabolic panels, thyroid function tests, and neuroimaging. We then had a neuroradiologist blinded to the clinical data review the magnetic resonance images (MRI) for hypothalamic hyperintensities. A Pubmed search was performed reviewing the incidence of SIADH in VGKC$\mathrm{LE}$ and other autoimmune syndromes. This study was approved by the institutional IRB.

\section{Results}

Paraneoplastic panel was resulted in 102 of the 848 patients. Six patients were positive for the VGKC antibody (mean age 62.5 years, 3 males). The mean time from clinical onset to diagnosis was 116 days (range 0 to 185 days). No evidence of malignancy on CT chest, abdomen, and pelvis was found in any of the six patients. Cerebrospinal fluid (CSF) results had an average white blood cell count of 4.0 cells/ $\mathrm{mm}^{3}$ (range 1 to 12 cells $/ \mathrm{mm}^{3}$; normal 0 to 5 cells $/ \mathrm{mm}^{3}$ ) and protein of $49.2 \mathrm{mg} / \mathrm{dL}$ (range 34 to $69 \mathrm{mg} / \mathrm{dL}$; normal 15 to $60 \mathrm{mg} / \mathrm{dL}$ ). The clinical features, VGKC titers and monitoring, and provided therapies are found in Table 1.
Average admission sodium was $130.7 \mathrm{mmol} / \mathrm{L}$ (range 115 to 141 $\mathrm{mmol} / \mathrm{L}$ ). Three patients had admission sodium levels less than 130 $\mathrm{mmol} / \mathrm{L}$ with an average of $122.7 \mathrm{mmol} / \mathrm{L}$ (range 115 to $128 \mathrm{nmol} / \mathrm{L}$ ). In these three patients, average urine osmolality was $579.7 \mathrm{mosm} / \mathrm{L}$ (range 505 to $677 \mathrm{mosm} / \mathrm{L}$ ) with urine sodium of $112.3 \mathrm{mmol} / \mathrm{L}$ (range 64 to $192 \mathrm{mmol} / \mathrm{L}$ ). Two of these three patients had hypothalamic involvement with T2/FLAIR hyperintensity seen on MRI brain. Water restriction was instituted during hospitalization for all three hyponatremic patients. Their hyponatremia resolved completely or partially prior to discharge with average serum sodium upon discharge of $133.0 \mathrm{nmol} / \mathrm{L}$ (range 126 to $137 \mathrm{nmol} / \mathrm{L}$ ). Basic metabolic workup and MRI findings can be seen in Table 2.

Serology for other autoimmune antibodies was negative in five of the cases. One case had positive microsomal antibodies $(138.6 \mathrm{IU} / \mathrm{mL}$; normal $<5 \mathrm{IU} / \mathrm{mL}$ ) and thyroglobulin antibodies $(1209 \mathrm{IU} / \mathrm{mL}$; normal $<10 \mathrm{IU} / \mathrm{mL}$ ) but normal thyroid stimulating hormone (TSH) $(4.63 \mathrm{uU} /$ $\mathrm{mL}$; normal 0.4 to $5.5 \mathrm{uU} / \mathrm{mL})$ and free $\mathrm{T} 4(1.2 \mathrm{ng} / \mathrm{dL}$; normal 0.7 to 1.8 $\mathrm{ng} / \mathrm{dL})$. None had diabetes.

\section{Discussion}

We present six cases of LE associated with the VGKC antibody. We found three of the six cases had SIADH consistent with the reported incidence in literature [1,3,5-9]. These cases responded completely or partially to the combination of immunomodulation and water restriction. Two of these three cases had hypothalamic involvement on MRI.

*Corresponding author: Christopher Newey, 1160 S Michigan Avenue \#3103 Chicago, IL 60605, USA, Tel: 216-444-2200; E-mail: crnewey@gmail.com

Received January 19, 2014; Accepted February 19, 2014; Published March 01, 2014

Citation: Newey CR, Sarwal A (2014) Hyponatremia and Voltage Gated Potassium Channel Antibody Associated Limbic Encephalitis. J Neurol Neurophysiol 5: 195. doi:10.4172/2155-9562.1000195

Copyright: (c) 2014 Newey CR, et al. This is an open-access article distributed under the terms of the Creative Commons Attribution License, which permits unrestricted use, distribution, and reproduction in any medium, provided the original author and source are credited. 


\begin{tabular}{|c|c|c|c|c|c|c|c|c|c|c|}
\hline Patient & $\begin{array}{l}\text { Age } \\
\text { (yrs); } \\
\text { Sex }\end{array}$ & $\begin{array}{l}\text { Clinical } \\
\text { Features }\end{array}$ & Cancer & $\begin{array}{c}\text { VGKC } \\
\text { Monitoring } \\
\text { (days) }\end{array}$ & $\begin{array}{c}\text { VGKC Titer } \\
\text { (nmol/L) Normal } \\
<0.02 \mathrm{nmol} / \mathrm{L}\end{array}$ & $\begin{array}{l}\text { CSF Protein } \\
\text { Results (mg/ } \\
\text { dL) Normal } \\
15-60 \mathrm{mg} / \mathrm{dL} \\
\end{array}$ & Treatment & AEDS & MRI & $\begin{array}{c}\text { Hypothalamic } \\
\text { Involvement on } \\
\text { MRI }\end{array}$ \\
\hline 1 & $93 \mathrm{~F}$ & $\begin{array}{l}\text { Altered mental } \\
\text { status }\end{array}$ & No & Initial & 0.13 & 57 & None & None & $\begin{array}{l}\text { Global atrophy, laminar } \\
\text { necrosis left parietal lobe }\end{array}$ & No \\
\hline \multirow[t]{4}{*}{2} & $60 \mathrm{M}$ & $\begin{array}{l}\text { Autonomic } \\
\text { seizure }\end{array}$ & No & Initial & 1.58 & NA & IVIG & LCM, LTG & $\begin{array}{l}\text { Bilateral mesial temporal } \\
\text { lobe hyperintensity }\end{array}$ & Yes \\
\hline & & & & 54 & 4.22 & & PLEX & & & \\
\hline & & & & 161 & 15.8 & & & & & \\
\hline & & & & 273 & 1.94 & & & & & \\
\hline 3 & $53 \mathrm{~F}$ & $\begin{array}{l}\text { Altered } \\
\text { mental status, } \\
\text { depression }\end{array}$ & No & Initial & 0.76 & 69 & $\begin{array}{l}\text { IVMP } \times 5 \text { days, } \\
\text { IVIG } \times 5 \text { days }\end{array}$ & LEV, LCM & $\begin{array}{l}\text { Bilateral hyperintensity in the } \\
\text { restiform bodies }\end{array}$ & No \\
\hline 4 & $55 \mathrm{M}$ & $\begin{array}{l}\text { Altered mental } \\
\text { status }\end{array}$ & No & Initial & 3.89 & 101 & $\begin{array}{l}\text { IVMP } \times 5 \text { days, } \\
\text { PLEX } \times 5 \text { days }\end{array}$ & $\begin{array}{l}\text { ZON, LEV, } \\
\text { LCM }\end{array}$ & $\begin{array}{l}\text { Right unilateral mesial } \\
\text { temporal lobe hyperintensity }\end{array}$ & No \\
\hline \multirow[t]{2}{*}{5} & $37 \mathrm{~F}$ & $\begin{array}{l}\text { Complex } \\
\text { partial seizure }\end{array}$ & No & Initial & 2.8 & 47 & $\begin{array}{l}\text { IVIG } \times 3 \text { days, } \\
\text { IVMP } \times 3 \text { days, } \\
\text { PLEX } \times 5 \text { days }\end{array}$ & $\begin{array}{l}\text { VPA, LEV, } \\
\text { PHT }\end{array}$ & $\begin{array}{l}\text { Bilateral basal ganglia/ } \\
\text { hippocampus hyperintensity }\end{array}$ & Yes \\
\hline & & & & 408 & 0.77 & & & & & \\
\hline 6 & $85 \mathrm{M}$ & $\begin{array}{l}\text { Altered mental } \\
\text { status, seizure }\end{array}$ & No & Initial & 0.692 & 48 & $\begin{array}{l}\text { IVMP } \times 5 \text { days, } \\
\text { PLEX } \times 3 \text { days/ } \\
\text { week for } 2 \\
\text { weeks }\end{array}$ & $\begin{array}{l}\text { VPA, LEV, } \\
\text { TPM }\end{array}$ & $\begin{array}{l}\text { Right unilateral mesial } \\
\text { temporal lobe hyperintensity }\end{array}$ & Yes \\
\hline
\end{tabular}

Abbreviations: $\mathrm{M}=$ male, $\mathrm{F}=$ female, $\mathrm{VGKC}=$ voltage gated potassium channel antibody, $\mathrm{CSF}=$ cerebrospinal fluid, IVMP=1 gram of intravenous methylprednisolone, $\mathrm{IVIG}=0.4 \mathrm{~g} / \mathrm{kg} / \mathrm{d}$ of intravenous immunoglobulin, PLEX=plasma exchange

Table 1: Characteristics of patients with serology positive for VGKC antibodies.

\begin{tabular}{|c|c|c|c|c|c|c|c|c|c|c|c|c|c|}
\hline Pt & $\begin{array}{l}\text { Admission } \\
\text { Sodium } \\
\text { (nmol/L) }\end{array}$ & $\begin{array}{l}\text { Discharge } \\
\text { Sodium } \\
\text { (nmol/L) }\end{array}$ & $\begin{array}{c}\text { Urine } \\
\text { Osmolality } \\
\text { (mOs/kg) }\end{array}$ & $\begin{array}{c}\text { Serum } \\
\text { Osmolality } \\
\text { (mOs/kg) }\end{array}$ & \begin{tabular}{|c|} 
Urine \\
Sodium \\
$(\mathrm{mmol} / \mathrm{L})$
\end{tabular} & $\begin{array}{c}\text { Serum } \\
\text { BUN (mg/ } \\
\text { dL) }\end{array}$ & $\begin{array}{c}\text { Serum } \\
\text { Creatinine } \\
(\mathrm{mg} / \mathrm{dL})\end{array}$ & $\begin{array}{c}\begin{array}{c}\text { Serum } \\
\text { Potassium } \\
\text { (mmol/L) }\end{array} \\
\end{array}$ & $\begin{array}{c}\text { TSH (uU/ } \\
\text { mL) }\end{array}$ & $\begin{array}{c}\text { Water } \\
\text { Restriction }\end{array}$ & Demecocycline & SIADH & $\begin{array}{c}\text { Formal } \\
\text { endocrinology } \\
\text { consult }\end{array}$ \\
\hline 1 & 141 & 137 & NA & NA & NA & 16 & 0.84 & 4.8 & 5.25 & NA & NA & No & No \\
\hline 2 & 139 & 137 & NA & NA & NA & 12 & 0.74 & 3.7 & 1.75 & NA & NA & No & No \\
\hline 3 & 136 & 141 & NA & NA & NA & 20 & 0.73 & 4 & 0.46 & NA & NA & No & No \\
\hline 4 & 115 & 126 & 677 & 264 & 192 & 6 & 0.51 & 3.7 & 4.63 & Yes & Yes & Yes & No \\
\hline 5 & 126 & 137 & 557 & 256 & 64 & 5 & 0.84 & 4.1 & 4.63 & Yes & Yes & Yes & Yes \\
\hline 6 & 128 & 136 & 505 & 276 & 81 & 26 & 0.75 & 4 & 1.64 & Yes & No & Yes & No \\
\hline
\end{tabular}

Table 2: Serum and urine laboratory findings.

VGKC proteins constitute a diverse group of tetrameric signaling proteins present on the cell surface different tissue subtypes [1]. These proteins classically have a vital role in cellular action potential and recently have been shown to initiate paraneoplastic autoimmunity as autoantigens [1]. VGKC antibodies are seen in neuromyotonia, Morvan syndrome, epilepsy, and dysautonomic phenomena of hyperhidrosis and gastrointestinal dysmotility [1,2]. Interestingly, hyponatremia is not seen in these disorders [10]. Reports have postulated that the leucine-rich, glioma inactivated 1 (LGI-1) protein may be the target antigen of VGKC mediated LE whereas the contactin-associated protein 2 (CASPR-2) may be the antigen in Issaac's and Morvan's syndrome [9].

The mechanism of SIADH in patients with VGKC-LE is not completely understood. One possible mechanism is inflammation on the hypothalamic-pituitary neuraxis from direct extension. Two of the three hyponatremic patients in our series had hypothalamic hyperintensity on T2/FLAIR MRI. If that's the case, all limbic encephalitis irrespective of the cause may have higher incidences of SIADH. Another possibility is involvement of the hypothalamic osmoreceptors regulating AVP release that are located in the lamina terminalis outside the blood brain barrier [8]. The predominant lack of an inflammatory response in CSF studies makes this mechanism less likely. The fact that most reports of hyponatremia improve with immunotherapy supports an antibody mediated mechanism with the target antigen either at the hypothalamus or perhaps at the Kv1.1 and/ or LGI-1 channels at the renal tubular epithelium, which could explain receptor sensitization and potentiating $\mathrm{ADH}$-induced water transport [7].

Future areas of research should focus on detailed endocrinological evaluation of hyponatremia in patients with autoimmune encephalitis distinguishing SIADH from other causes of hyponatremia, such as cerebral salt wasting. Additionally, the histopathological query of hypothalamic and renal involvement in animal models of autoimmune encephalitis investigating VKGC as well as LGI-1 antibodies in hyponatremic animals would be beneficial to accurately define the causative protein for SIADH in VGKC-LE. The specificity of hyponatermia to VKGC-LE versus other causes of autoimmune encephalitis should also be explored. With the emerging VGKC subtypes and new antigen targets for VGKC antibody associated diseases, it is evident that the associations of LE and secondary features are complex. Our case series emphasizes the association and an early diagnosis of LE given the reversibility with a combination of water restriction and immunomodulation.

\section{Acknowledgements}

Dr. Surafel Gebreselassie, nephrology, for critical appraisal. Dr. Thinesh Sivapatham, neuroradiology, for reviewing MRI images.

\section{References}

1. Tan KM, Lennon VA, Klein CJ, Boeve BF, Pittock SJ (2008) Clinical spectrum of voltage-gated potassium channel autoimmunity. Neurology 70: 1883-1890. 
Citation: Newey CR, Sarwal A (2014) Hyponatremia and Voltage Gated Potassium Channel Antibody Associated Limbic Encephalitis. J Neurol Neurophysiol 5: 195. doi:10.4172/2155-9562.1000195

Page 3 of 3

2. Vernino S, Geschwind M, Boeve B (2007) Autoimmune encephalopathies. Neurologist 13: 140-147.

3. Vincent A, Buckley C, Schott JM, Baker I, Dewar BK, et al. (2004) Potassium channel antibody-associated encephalopathy: a potentially immunotherapyresponsive form of limbic encephalitis. Brain 127: 701-712.

4. Graus F, Saiz A, Dalmau J (2010) Antibodies and neuronal autoimmune disorders of the CNS. J Neurol 257: 509-517.

5. Geschwind MD, Tan KM, Lennon VA, Barajas RF Jr, Haman A, et al. (2008) Voltage-gated potassium channel autoimmunity mimicking creutzfeldt-jakob disease. Arch Neurol 65: 1341-1346.

6. Thieben MJ, Lennon VA, Boeve BF, Aksamit AJ, Keegan M, et al. (2004) Potentially reversible autoimmune limbic encephalitis with neuronal potassium channel antibody. Neurology 62: 1177-1182.
7. Ances BM, Vitaliani R, Taylor RA, Liebeskind DS, Voloschin A, et al. (2005) Treatment-responsive limbic encephalitis identified by neuropil antibodies: MRI and PET correlates. Brain 128: 1764-1777.

8. Chan D, Henley SM, Rossor MN, Warrington EK (2007) Extensive and temporally ungraded retrograde amnesia in encephalitis associated with antibodies to voltage-gated potassium channels. Arch Neurol 64: 404-410.

9. Lai M, Huijbers MG, Lancaster E, Graus F, Bataller L, et al. (2010) Investigation of LGI1 as the antigen in limbic encephalitis previously attributed to potassium channels: a case series. Lancet Neurol 9: 776-785.

10. Merchut MP (2010) Management of voltage-gated potassium channel antibody disorders. Neurol Clin 28: 941-959. 